\title{
Ethical Justification in Medical Futility and Advanced Medical Directive from The Islamic Perspective
}

Ariff Osman ${ }^{1}$, Che Anuar Che Mohamad ${ }^{2}$, Faizatul Najihah Mohd Azaman ${ }^{3}$, Muhamad Rasydan Abd Ghani ${ }^{1}$, Mohammad Arif Shahar ${ }^{4}$, Mohd Faiz Tahir ${ }^{5}$, Muhamad Shahrir Abdul Rahim ${ }^{6}$, Mek Wok Mahmud ${ }^{3}$, Hasbullah Mohamad ${ }^{7}$

${ }^{1}$ Department of Anaesthesiology and Intensive Care, Kulliyyah of Medicine, International Islamic University Malaysia (IIUM)

${ }^{2}$ Department of Basic Medical Sciences, Kulliyyah of Pharmacy, IIUM

${ }^{3}$ Department of Fiqh and Usul Fiqh, Kulliyyah of Islamic Revealed Knowledge and Human Sciences, IIUM

${ }^{4}$ Department of Internal Medicine, Kulliyyah of Medicine, IIUM

${ }^{5}$ Department of Psychiatry, Kulliyyah of Medicine, IIUM

${ }^{6}$ Department of Radiology, Kulliyyah of Medicine, IIUM

${ }^{7}$ Department of Fundamental Knowledge and Interdisciplinary Studies, Kulliyyah of Islamic Revealed Knowledge and Human Sciences, IIUM

Presenter: Ariff Osman

Introduction: Medical futility and advanced medical directive are related issues in end-of-life medical decisions that present challenge to doctors and patients in terminal condition and to doctors and family members of patients who are critically ill in the ICU. Materials and Methods: A qualitative study comprises of literature search and an in-depth interview of experts was carried out to determine the clinical situations in medical futility and the ethical considerations from the Islamic perspective that justify forgoing medical treatment and also the practice of advanced medical directives in the country. Results: In such scenarios, clinical data must be interpreted alongside patient values, as well as the physicians' ethical commitments. From the Islamic perspective, doctors are the authorised person to diagnose medical futility and forgo medical treatment. Forgoing treatment is permissible as long as it conforms to the maqasid and qawaid al-shariah principles that guide the decision-making process. The practice of advanced medical directive is still at its infancy in this country. From the Islamic perspective, upon considering the maqasid and qawaid al-shariah principles, it should be permissible and its practice should be encouraged as it assists the doctors and the surrogate decision-maker to decide to the withdrawal of treatment. Conclusion: Ethical justification on medical futility conforms to the maqasid and qawaid al-shariah principles and forgoing medical treatment is permissible in Islam. Advanced medical directive assists in the decision-making of forgoing treatment in the presence of utility and thus its practice should be promoted. 